\title{
EDITORIAL
}

\section{Opening to the Australian Journal of Environmental Education Special 30-Year Anniversary Issue}

2014 represents the 30th year of the Australian Journal of Environmental Education $(A J E E)$, making it one of the oldest academic journals in environmental education still in publication. The oldest is The Journal of Environmental Education, founded in 1969. Another journal, The International Journal of Environmental Education and Information, was founded in 1981 but is no longer in publication, and the Southern African Journal of Environmental Education, also founded in 1984, has not had any issues since 2011.

The seeds for the AJEE were sown at the 1982 conference of the Australian Association for Environmental Education (AAEE), and the initial vision for the journal was 'to present information and argument which will stimulate debate about educational activities to enhance environmental awareness, understanding and action among all Australians'. Although there was always an intention to publish research, this focus for the journal became more significant as the journal evolved, such that the AJEE is now an international refereed journal that 'publishes papers and reports on all aspects of environmental education. It presents information and argument which stimulates debate about educational strategies that enhance the kinds of awareness, understanding and actions which will promote environmental and social justice'.

The context for environmental education at the time the idea for the AAEE to have a journal was conceived was a busy one: the World Conservation Strategy had been released in 1980, and individual countries were in the process of formulating their national responses (a National Conservation Strategy for Australia was developed in 1983 with significant involvement from AAEE members in the Education section). Environmental issues, such as the damming of the Franklin River, the commencement of the Ranger Uranium project, the declaration of Australia's first UNESCO World Heritage sites, drought in some parts of Australia and land clearing were in the media, and most states and territories had environmental education officers within their education departments to support teachers with implementing environmental education in schools. Thirty years on there is less support from state governments for environmental education in schools, but environmental issues are still in the media; although nowadays it is climate change, extension of freeways in inner suburban areas, drought in some parts of Australia, and the impact of land clearing and sea dumping, with at least two of our UNESCO World Heritage sites under threat. Some things change, and some remain the same - and the AJEE is still here.

In celebration of this significant milestone for the journal and the AAEE, we are publishing a Special 30th Anniversary Issue. This 30-Year Special Issue has been edited by Associate Professor Amy Cutter-Mackenzie (Current Editor), Professor Annette Gough (Past Editor), Professor Noel Gough (Past Editor) and Associate Professor Hilary Whitehouse (Editorial Board Member). This Special Issue includes the most significant 
articles previously published in the journal, in terms of impact, quality and scholarship, judged against three core criteria:

- Research impact, quality and scholarship. These measures were based on citations and peer review criteria similar to those deployed by the Excellence for Research in Australia (ERA) initiative;

- Relevance in 2014 (especially for early career and aspiring researchers); and

- Appeal to the AAEE membership.

In addition, each article's author was invited to provide a short response to her/his article, and these are included in this issue following the respective article, along with any new contact details and affiliations.

The articles selected represent a wide range of perspectives on environmental education. From the first issue (1984) came Robottom's germinal essay, 'Why not educate for the environment?' In Volume 3 (1987), Di Chiro wrote the first feminist critique in Australian environmental education literature. From Volume 7 (1991) came two important reflections for environmental education research: Huckle's influential (and very widely cited) paper on education for sustainability and critical theory and N. Gough's pioneering article, which was the first time poststructuralism was invoked in English-language environmental education literature. From Volume 9 (1993) came Jickling's article on the importance of conceptual analysis in researching environmental education. Volume 14 (1998) was the source of three contributions to this special issue: Payne's article on children and nature; Connell, Fien, Sykes, and Yencken's quantitative study of young people and environment in Australia; and van Rensburg and Hillcoat's important article on malconsumption, which has particular relevance today. Volume 22 (2006) was also the source of three articles: A. Gough's reflection on the road to education for sustainability in Australia; Stewart's reflection on outdoor education and natural history, and Cutter-Mackenzie and Edwards' article on early childhood environmental education. Factors influencing environmental education teacher education were discussed by Ferreira, Ryan, and Tilbury in Volume 23 (2007); and finally, we have included from Volume 26 (2010), Whitehouse's practice-based research on 'Not "Greenies" at school'.

As well as the articles and response pieces, the editors have also written individual reflections on the journal over the past 30 years, which are interspersed throughout the Special Issue. The foci for these individual pieces are: (1) Historical Perspectives in AJEE (A. Gough); (2) Research Methodologies Represented (or Not) in AJEE (N. Gough); (3) Where are Children and Young People in Environmental Education Research? (Cutter-Mackenzie); and (4) Gender and Other Forms of Difference/Diversity (Whitehouse).

In compiling this Special Issue of the AJEE, we would like to pay tribute to all past and present editors for the contributions they have made: Bill Carter (Vol. 1); Mary Maher, Ron Tooth and Malcolm Cox (Vol. 2); Ian Robottom (Vols. 3-11); Richard Smith (Vols. 12-14); Annette Gough, Noel Gough, John Fien and Debbie Heck (Vols. 15-18); Roy Ballantyne (Vols. 19-21), Jo-Anne Ferreira (Vols. 19-25), Phillip Payne (Vol. 26) and Amy Cutter-Mackenzie (Vols. 26-30). Without their willingness to generously volunteer their time and passion for environmental education (and its research) to maintain and grow the journal, we would not be editing this special issue.

We hope that you enjoy this special issue of the journal and that this opportunity to read some of the key articles from the past 30 years of $A J E E$ will stimulate you to continue to engage in debates about educational strategies that promote environmental and social justice. 